\title{
Bartosz Krzan, Odpowiedzialność państwa członkowskiego z tytułu działalności organizacji międzynarodowych (Responsibility of a Member State for the Acts of International Organizations), (Wydawnictwo Uniwersytetu Wrocławskiego, Wrocław 2013), 283 pp., ISBN 978-83-229-3383-1
}

It is a generally settled principle of international law that whenever a duty established by any of its rules has been breached by act or omission, a new legal relationship automatically comes into existence - an obligation to make some form of reparation ${ }^{1}$. As far as responsibility of states is concerned, the International Law Commission prepared Articles on Responsibility of States for Internationally Wrongful Acts in $2001^{2}$. These articles do not however address the issue of responsibility of international organizations, hence in 2011, on its second reading, the ILC adopted the (draft) Articles on the Responsibility of International Organizations ${ }^{3}$. On its part, the Institute of International Law in 1995 published a 'private' codification on that subject ${ }^{4}$

1 E. Jimenez de Aréchaga, A. Tanzi, International State Responsibility, [in:] M. Bedjaoui, 'International Law: Achievements and Prospects', Martinus Nijhoff Publishers, Dordrecht 1991, p. 347, at p. 347.

2 Report of the International Law Commission on the Work of its Fifty-third Session, UN GAOR 56th Session, Supp. No. 10 (A/56/10), at p. 43.

3 Report of the International Law Commission on the Work of its Sixty-third Session, UN GAOR 66th Session, Supp. No. 10 (A/66/10 and Add. 1), at p. 54.

4 Institute de Droit International, Session of Lisbonne - 1995, The Legal Consequences for Member States of the Non-fulfilment by International Organizations of their Obligations toward Third Parties. 
The topic of responsibility of Member States for the (wrongful) acts of international organizations has already been explored in scholarly literature ${ }^{5}$. The book by Krzan is therefore among first major publications that comprehensively examine the topic at issue.

The aim of the book under review is to analyze the circumstances concerning the responsibility of State member of an international organization for the activities of that organization. Therefore the topic at hand is vital to various activities of international organizations in terms of allocating responsibility, as well as because of problems with availability of proper forum for its realization.

The book falls into four Chapters followed by the short concluding remarks. They deal in turn with the responsibility in international law (Chapter I), independent responsibility (Chapter II), attribution of responsibility (Chapter III), content and the implementation of responsibility (Chapter IV).

In Chapter I the author examines the notion of responsibility in international law. It begins with the general remarks on this subject as to the essence of international responsibility, its codification with respect to states and the specificity of responsibility of international organizations. The author is proficient in explaining the notion of responsibility of international organizations according to the works of International Law Commission and rightly underscores that the specificity of international organizations not always allows for invoking their international responsibility. This problem has had its particular significance since the cases of Westland Helicopters v. Arab Organization for Industrialization and International Tin Council in the last decades of XXth century.

The second Chapter of the book is devoted to independent responsibility. The author expertly analyses the complex issues concerning breaches of international obligations according to codifications of International Law Commission on international responsibility both of states as well as international organizations. In following sections Krzan describes circumstances precluding wrongfulness and the problems with attribution

5 See eg. J. M. Cortés Martín, The Responsibility of Members Due to Wrongful Acts of International Organizations, 'Chinese Journal of International Law' 2013, vol. 12, pp. 679-721, O. Murray, Piercing the Corporate Veil: The Responsibility of Member States of an International Organization, 'International Organizations Law Review' 2011, vol. 8, pp. 291-347, M. Hirsch, The Responsibility of International Organizations Toward Third Parties; Some Basic Principles, The Hague 1995. 
of acts within the framework of international organization. Subsequently the author analyses the rules of attribution of the acts of international organizations, including conduct of their organs or agents, conduct of organs of a State or organs or agents of an international organization placed at the disposal of another international organizations. The excess of authority or contravention of instructions (acts ultra vires) by organs or agents of international organizations and conduct acknowledged and adopted by an international organizations are also discussed by Krzan. Finally in Chapter II the author considers questions of dual or even multiple attribution of conduct to a States or other international organizations. The chapter is well documented with details from case law of the European Court of Human Rights (eg. Al-Jedda, Behrami) and some national courts (Srebrenica case before Dutch courts). Finally, Krzan notes that responsibility of Member States due to the wrongful acts of international organizations seems to be based on indirect responsibility as confronted with the independent responsibility. Practice has shown however that precise demarcation of the scope of international obligation with regard to international organization or its Member States proves to be difficult.

Chapter III concerns the attribution of responsibility. The author begins by discussing the issue of responsibility for acts of other subjects of law, the issue of aid or assistance by a Member State in the commission of wrongful act by an international organization, the direction and control by a Member State over the commission of wrongful act, the coercion of an international organization by a Member State and the circumvention of international obligations of a State member of an international organization. Then acceptance of responsibility of a Member State and its succession in case of extinction of an international organization. In Chapter III the author points out that international practice shows that the attribution of responsibility for acts of other subjects of international law is relatively rare. In order to be responsible for acts of international organization, Member State has to demonstrate on its part certain degree of involvement in committing wrongful act by that organization, for example in assisting or coercing the organization. In Krzan's words it is extremely difficult to justify the responsibility of a Member State only on the basis of its membership in the international organization. This would also contradict with the separate legal personality of international organizations.

Chapter IV traces the issues of content and forms reparation for the injuries caused by the internationally wrongful acts of international organizations. Of note too is the fact that in his book Krzan discusses the problem of serious breaches of obligations under peremptory norms of 
general international law. In his opinion the Articles on the Responsibility of International Organizations have introduced in this context certain form of regularity into the regime of international responsibility, what makes the concept of peremptory norms better-established. The probability of breaching peremptory norms by international organizations seems to be however lesser than in the case of states. In the final section of Chapter IV Krzan correctly observes that for holding Member State to be responsible for activities of international organization proves to be difficult. The fundamental obstacle is the autonomy of Member States vis-a-vis the organization. Separate legal personality of international organizations precludes in principle the possibility of invoking the responsibility of their Member States. In Chapter IV Krzan notes as well that the allocation of responsibility in case of multiplicity of legal subjects is complicated hence solutions to this problem should be found on a case by case basis.

Apart from the above remarks, Krzan's book raises also a few additional questions.

It seems, for instance, that Krzan uses the terms 'responsibility' and 'liability' of international organizations interchangeably. It must however be noted that for some authors those two terms do not necessarily mean the same ${ }^{6}$. Indeed even for some international organizations their act if committed in violation of international obligation entails the international responsibility of the Organization and its liability in compensation"? Furthermore Krzan introduces in his book the notion of 'accountability' (at p. 48) of international organizations as defined by the International Law Association in its Final Report of $2004^{8}$. The author could have said more therefore on the relationships concerning 'responsibility', 'liability' and 'accountability' as this would certainly be beneficial to his book.

There is also little mentioned on the binding force of human rights rules with regard to international organizations. Krzan has noticed

6 As to the differences between 'responsiblity' and 'liability' see. C. Ryngaert, $\mathrm{H}$. Buchanan, Member State responsibility for the acts of international organizations, 'Utrecht Law Review' 2011, vol. 7, no. 1, p. 131, at p. 133.

7 Letter of 3.2.2004 by the United Nations Legal Counsel to the Director of the Codification Division, UN Doc. A/CN.4/545, cited in Draft Articles on the Responsibility of International Organizations, Report of the Law Commission on the Work of its Sixty-First Session, GAOR, 64th Session, Supp. No. 10, (A/64/10) (2009), at p. 64 .

8 International Law Association, Berlin Conference (2004), Accountability of International Organizations, Final Report. 
the problems resulting from the activities of international organizations breaching human rights treaties binding on their Member States (at p. 87). He has not however decisively adjudicated, whether the principle of 'nemo plus iuris in alium transferre potest quam ipse habet' shall be applied to the Member States of an international organization whose acts have violated human rights.

It should also be noted that some parts of the book are somewhat descriptive and could have benefited from more vigorous analysis of some key documents. This would help the author to present some more conclusions concerning de lege ferenda on responsibility of Member State for the acts of international organizations.

Despite some criticism, Krzan's book will remain a source of interest to all of those working in the field of international responsibility of states and international organizations. It also retains significance for scholars and practitioners interested in wider questions, that arise with regard to the international institutional law and 'complex interrelations between the international organizations and their Member States'.

Marek Zieliński ${ }^{10}$

9 Quoted from the English summary of the book, at p. 283.

10 Marek Zieliński, Professor, Faculty of Law and Administration, University of Silesia in Katowice. 